JKEP

Vol 3, No 2, November 2018

ISSN: 2354-6042 (Print)

ISSN : 2354-6050 (Online)

\title{
Pengaruh Psikoedukasi terhadap Pengetahuan dan Tingkat Kecemasan Pasien dengan hipertensi
}

\author{
Omi Haryati, Nurdiana \\ Jurusan Keperawatan Poltekkes Kemenkes Jakarta III \\ Email:Omi.haryati@yahoo.co.id
}

\author{
Artikel history \\ Dikirim, Sept $28^{\text {th }}, 2018$ \\ Ditinjau, Okt15 ${ }^{\text {th }}, 2018$ \\ Diterima, Okt 30 ${ }^{\text {th }}, 2018$
}

\begin{abstract}
Psychoeducation is the provision of information about managing disease and the psychological aspects of patients. Psychoeducation teaches someone about a problem so they can reduce the stress associated with the problem. Relaxation can reduce muscle tension, saturation and anxiety so as to prevent the increase in pain stimuli and can help hypertensive patients to reduce anxiety and strengthen individual coping. This study aims to determine the effect of psychoeducation on the knowledge and anxiety level of patients with hypertension. The study design was a quasi-experimental pre-post test with control group psychoeducation intervention with a sample of 80 people. The results were significant differences in the knowledge of patients before and after the intervention group ( $p$ value knowledge $=0.013$ ), whereas in the control group there was no difference ( $p$ value $=0.770$ ). The conclusion is obtained that psychoeducation can improve the knowledge of patients with hypertension, so that it is expected to be one form of intervention that can be applied to the community in the Cipayung District area. Key Word : Psicoeducation; Hypertension; Anxiety
\end{abstract}




\begin{abstract}
ABSTRAK
Psikoedukasi merupakan pembeian informasi tentang pengeloaan penyakit dan aspek psikologik pasien. Psikoedukasi mengajarkan seseorang mengenai suatu masalah sehingga mereka bisa menurunkan stres yang terkait dengan masalah tersebut. Relaksasi dapat mengurangi ketegangan otot, rasa jenuh dan kecemasn sehingga mencegah menghebatnya stimulus nyeri dan dapat membantu pasien hipertensi untuk menurunkan kecemasan dan memperkuat koping individu. Penelitian ini bertujuan untuk mengetahui pengaruh psikoedukasi terhadap pengetahuan dan tingkat kecemasan pasien dengan hipertensi. Desain penelitian adalah quasi eksperiment pre-post test with control group dilakukan intervensi psikoedukasi dengan jumlah sampel 80 orang. Hasil penelitian memperlihatkan ada perbedaan yang bermakna tingkat pengetahuan pasien sebelum dan sesudah pada kelompok intervensi $(\mathrm{p}$-value $=0.013)$, sedangkan pada kelompok kontrol tidak ada perbedaan $(\mathrm{p}$ value $=0.770$ ). Kesimpulan yang diperoleh adalah psikoedukasi dapat meningkatkan pengetahuan pasien dengan hipertensi, sehingga diharapkan dapat menjadi salah satu bentuk intervensi yang dapat diterapkan terhadap masyarakat di wilayah Kecamatan Cipayung.
\end{abstract}

Kata Kunci : Psikoedukasi; hipertensi; kecemasan

\section{PENDAHULUAN}

Prevalensi Hipertensi atau tekanan darah tinggi di Indonesia cukup tinggi. Selain itu, akibat yang ditimbulkannya menjadi masalah kesehatan masyarakat. Hipertensi, merupakan salah satu faktor risiko yang paling berpengaruh terhadap kejadian penyakit jantung dan pembuluh darah. Hipertensi sering tidak menunjukkan gejala, sehingga baru disadari bila telah menyebabkan gangguan organ seperti gangguan fungsi jantung atau stroke. Tidak jarang hipertensi ditemukan secara tidak sengaja pada waktu pemeriksaan kesehatan rutin atau datang dengan keluhan lain (Prof. dr. Tjandra Yoga Aditama).
Kecemasan merupakan suatu respon terhadap situasi yang penuh dengan tekanan. Stres dapat didefinisikan sebagai suatu persepsi ancaman terhadap suatu harapan yang mencetuskan cemas (Rawlins, at al, 1993). Stress dapat berbentuk psikologis, sosial atau fisik. Hal ini menunjukkan bahwa ansietas yang dialami oleh individu bersifat subyektif dan tidak sama satu sama lainnya. Umumnya pasien dan keluarga hanya mendapatkan pendidikan kesehatan terkait penyakit yang diderita pasien. Diharapkan dengan Psikoedukasi dapat membantu pasien hipertensi untuk menurunkan kecemasan dan memperkuat koping individu. 
Psikoedukasi suatu intervensi yang dapat dilakukan pada individu, keluarga dan kelompok yang fokus pada mendidik partisipasinya mengenai tantangan signifikan dalam hidup, membantu partisipan mengembangkan sumber sumber dukungan dan dukungan sosial dalam menghadapi tantangan tersebut dan mengembangkan ketrampilan coping untuk menghadapi tantangan tersebut (Grifith, 2006 dikutip dari Walsh, 2010).

Penelitian ini bertujuan untuk mengetahui pengaruh psikoedukasi pasien dengan hipertensi dalam meningkatkan pengetahuan dan menurunkan kecemasannya. Selain pemeriksaan kesehatan, dilakukan pemeriksaan kesehatan jiwa dengan penyebaran quesioner untuk mengetahui tingkat kecemasan pasien dengan hipertensi. Dari hasil ini peneliti tertarik untuk melakukan penelitian tentang pengaruh psikoedukasi pasien dengan hipertensi dalam menurunkan tingkat kecemasan.

\section{METODE}

Desain yang digunakan dalam penelitian ini adalah Quasi experimental pre-post test with control group design dengan paket intervensi terapi psikoedukasi pada keluarga dengan hipertensi. Penelitian dilakukan diwilayah Puskesmas Kelurahan Cipayung Jakarta Timur dari bulan Januari sampai minggu terakhir Agustus 2018. Penelitian ini dilakukan di dua tempat yang berbeda, untuk kelompok kontrol adalah wilayah RW 08, dalam pelaksanaan program prolanis untuk warga yang hipertensi, sementara untuk kelompok intervensi dilakukan di RW 02.

Intervensi penelitian adalah psikoedukasi yang dilakukan pada kelompok intervensi berupa penyuluhan kesehatan sebanyak 1 kali. Penyuluhan kesehatan yang diberikan berupa materi tentang hipertensi dan kecemasan dan perawatannya dengan metode ceramah dan pada akhir sesi diberikan kesempatan diskusi dan tanya jawab. Psikoedukasi yang diberikan berupa psikoedukasi aktif dan pasif. Psikoedukasi aktif yang dilakukan yaitu dengan konseling, sedangkan psikoedukasi pasif dengan cara pemberian booklet kepada responden setelah diberikan konseling. Pemberian psikoedukasi pasif dimaksudkan untuk melengkapi 
psikoedukasi aktif atau konseling yang telah dilakukan, dengan tujuan agar responden bisa mempelajari kembali apa yang sudah didiskusikan di puskesmas.

Media yang digunakan dalam penyuluhan kesehatan ini adalah materi yang disampaikan dengan menggunakan modul dan leaflet. Waktu yang dibutuhkan adalah 60 menit. Kelompok intervensi diberikan terapi psikoedukasi selama 5 minggu dengan 5 sesi, setiap sesi 1 kali pertemuan yaitu: identifikasi masalah , pendidikan kesehatan, manajemen ansietas,. Pelaksanaan terapi psikoedukasi ini dilakukan ke kelompok dengan durasi waktu $30-60$ menit Setelah pemberian intervensi selesai peneliti melakukan post test berupa pengukuran kembali terhadap ansietas dengan menggunakan instrumen yang sama pada saat pre test.

Populasi dalam penelitian ini adalah pasien dengan hipertensi. Sampel penelitian ini adalah pasien dengan hipertensi sesuai dengan kriteria inklusi: pasien dengan hipertensi tekanan diastoliknya $\geq 95 \mathrm{mmHg}$, dan pasien kooperatif. Teknik pengambilan sampel dilakukan dengan cluster random sampling yaitu pengambilan sampel sedemikian rupa sehingga setiap unit dasar (individu) mempunyai kesempatan yang sama untuk diambil sebagai sampel (Polit \&Hungler, 2006).

Pengumpulan data primer pada penelitian ini dilakukan dengan menggunakan pedoman wawancara, observasi dan kuisioner sebagai instrumen penelitian untuk mengidentifikasi penurunan tingkat ansietas.

a. Instrumen data demografi: merupakan instrumen untuk mendapatkan gambaran karakteristik keluarga yang terdiri dari: usia, jenis kelamin, pendidikan, pekerjaan, pendapatan dan status perkawinan. Bentuk pertanyaan dalam bentuk pertanyaan tertutup dan peneliti memberi jawaban yang tersedia, sesuai dengan option yang dipilih oleh responden.

b. Instrumen penelitian untuk mengukur tingkat kecemasan dengan menggunakan skala HARS pada kelompok kontrol dan intervensi

c. Instrumen penelitian untuk mengukur pengetahuan responden kelompok kontrol dan intervensi 
dalam merawat keluarga yang hipertensi

Data yang telah dikumpulkan selanjutnya diolah dengan menggunakan program SPSS versi 22. Analisis univariat dilakukan untuk mendeskripsikan karakteristik setiap variabel yang diukur dalam penelitian. Karakteristik responden yang meliputi usia, jenis kelamin, pendidikan, pekerjaan, status perkawinan, dianalisis untuk menghitung frekuensi dan persentase variabel. Kemampuan responden (kognitif dan psikomotor) merupakan data numerik yang dianalisis untuk menghitung mean, median, standar deviasi, confidence interval 95\%, nilai maksimal dan minimal. Penyajian data masing-masing variabel dalam bentuk tabel dan diinterpretasikan berdasarkan hasil yang diperoleh.

Analisis Bivariat dilakukan untuk mengetahui perbedaan pengetahuan dan tingkat kecemasan pasien sebelum dan sesudah psikoedukasi pada kelompok intervensi dan kelompok kotrol digunakan dependent $t$ test. Analisis multivariat menggunakan uji mancova untuk membuktikan pengaruh karakteristik pasien terhadap pengetahuan dan tingkat kecemasan

\section{HASIL DAN PEMBAHASAN}

Berdasarkan hasil penelitian respoden pada kelompok kontrol rata rata berusia pada lansia awal dan lansia akhir, sedangkan pada kelompok intervensi responden rata rata berusia pada dewasa akhir dan lansia awal. Responden pada kelompok kontrol dan intervesi berjenis kelamin wanita, rata rata tidak bekerja, rata rata sudah menikah. Untuk tingkat pendidikan pada kelompok intervensi lebih tinggi dari pada kontrol, rata rata pada kelompok intervensi adalah SMP dan SMA sedangkan pada kelompok kontrol sebagian besar berpendidikan SD. Pada pre test, tingkat kecemasan ringan pada kelompok kontrol sebesar $65 \%$ dan pada post test meningkat 77.5 $\%$. Sementara pada kelompok intervensi tingkat kecemasan ringan pada pre test adalah $77.5 \%$ dan pada post test meningkat menjadi $82.5 \%$. Pengetahuan responden pada kelompok kontrol untuk pre dan post adalah 97.5 $\%$. Sementara pada kelompok intervensi untuk pre test adalah $100 \%$ dan post test adalah $97.5 \%$.

Pada distribusi tekanan darah pada kelompok kontrol rata rata tekanan darah sistole $137.88 \mathrm{mmHg}$ dengan 
standar deviasi 24.982 dan rata rata tekanan diastol $81.93 \mathrm{mmHg}$, dengan standar deviasi 10.279. Pada kelompok intervensi tekanan darah sistol rata rata 124.98 dengan standar deviasi 17.631 dan tekanan darah diastole rata rata 83.38 dengan standar deviasi 11.417. Tekanan darah sistole pada kelompok kontrol lebih tinggi dibandingkan kelompok intervensi. Tekanan darah

pada kelompok kontrol minimal 100 dan maximal 210. Pada kelompok intervensi minimal 100 maximal 170. Terdapat perbedaan signifikan antara tekanan darah pada kelompok kontrol dan intervensi dengan $\mathrm{p}$-value $=0.009$. Sementara untuk tekanan diastole pada kelompok kontrol dan intervensi tidak ada perbedaan dengan nilai $\mathrm{p}$-value $=$ 0.543 .

Tabel 1

Distribusi data sistolik dan diastolik pada kelompok kontrol dan intervensi

\begin{tabular}{llllllll}
\hline Variabel & kelompok & Mean & Median & Min - Max & SD & SE & P Value \\
\hline Sistole & Kontrol & 137.88 & 130 & $100-210$ & 24.982 & 3.950 & 0.009 \\
& Intervensi & 124.98 & 120 & $100-170$ & 17.631 & 2.788 & \\
\multirow{2}{*}{ Diastole } & Kontrol & 81.93 & 80 & $60-110$ & 10.279 & 1.625 & 0.543 \\
& Intervensi & 83.38 & 86 & $60-100$ & 11.417 & 1.805 & \\
\hline
\end{tabular}

Perbedaan tekanan darah dapat pada kelompok kontrol dan intervensi dapat dikarenakan karena adanya perbedaan umur, semakin bertambah usia, pembuluh darah kita semakin kaku, tidak elastis lagi. Akibatnya, tekanan darah pun semakin meningkat. Menurut Lany Gunawan (2001), ciri perseorangan yang mempengaruhi timbulnya hipertensi adalah umur (jika umur bertambah maka TD meningkat), jenis kelamin (laki-laki lebih tinggi dari perempuan ) dan ras (ras kulit hitam lebih banyak dari kulit putih). Pada penelitian ini respondennya berjenis kelamin perempuan semua, sehingga mempunyai kesamaan pada kelompok kontrol dan intervensi. Hal ini sesuai dengan responden penelitian yang sebagian besar lansia yaitu jika umur bertambah maka tekanan darah akan akan meningkat. Hal ini sesuai penelitian Novaningyas (2014) bahwa $80 \%$ perempuan menderita hipertensi dan berdasarkan umur usia lansia (82.5 $\%)$. Penyakit hipertensi pada pra lansia yang bersifat menahun mengakibatkan munculnya berbagai permasalahan, baik fisik maupun psikososial, dan berdampak pada diri lansia berupa 
respons stress yang berkelanjutan (Miller 2004). Dampak stress dapat memicu peningkatan tekanan darah.

Tabel 2 memperlihatkan rata rata respon cemas pada pre kontrol adalah 64.40 dengan standar deviasi 21.032 sedang untuk kelompok pos kontrol rata rata 60.70 dengan standar deviasi 18.910 hasil uji statistik didapatkan nilai pvalue $=0.442$ berarti pada alpha $5 \%$ terlihat tidak ada perbedaan yang signifikan rata rata kecemasan pada pre dan post kelompok kontrol. Pada kelompok intervensi rata rata respon cemas pada pre intrvensi adalah 58.20 dengan standar deviasi 27.593 sedang untuk kelompok pos intervensi rata rata 58.25 dengan standar deviasi 22.543. Hasil uji statistik didapatkan nilai pvalue $=0.993$ berarti pada alpha $5 \%$ terlihat tidak ada perbedaan yang signifikan rata rata kecemasan pada pre dan post kelompok intervensi.

Hal ini sesuai dengan hasil penelitian Faizatur Rohmi dkk (2015) tentang pengaruh psikoedukasi keluarga terhadap tingkat kecemasan dan kemampuan keluarga dalam merawat penderita TB diketahui bahwa nilai pvalue kecemasan pada kelompok kontrol sebesar $0,083 \quad(\mathrm{P} \geq 0,05) \quad$ yang berarti tidak ada perbedaan tingkat kecemasan yang bermakna sebelum dan sesudah dilakukan penyuluhan pada kelompok kontrol. Hal ini dapat dimungkinkan karena responden sudah menderita hipertensi yang lama atau responden sudah terbiasa dengan penyakitnya. Responden rutin melakukan pemeriksaan dan sering mendapat pendidikan kesehatan dari petugas kesehatan Puskesmas. Begitu juga pada hasil penelitian Aisyah Dzil Kamalah (2016) yang menyatakan ada perbedaan tingkat kecemasan yang signifikan pada keluarga penderita TB. Responden sudah mengganggap hipertensi menjadi penyakit yang biasa, dan tidak menyebabkan kecemasan. 


\begin{tabular}{llllll}
\hline \multicolumn{1}{c}{ Variabel } & & Mean & SD & SE & p-value \\
\hline Kontrol & Pre & 64.40 & 21.032 & 3.325 & 0.442 \\
& Pos & 60.70 & 18.910 & 2.990 & \\
Intervensi & Pre & 58.20 & 27.593 & 4.363 & 0.993 \\
& Pos & 58.25 & 22.543 & 3.564 & \\
\hline
\end{tabular}

Setiap perubahan dalam kehidupan atau peristiwa kehidupan yang dapat menimbulkan keadaan stres disebut stresor. Stres yang dialami seseorang dapat menimbulkan kecemasan, atau kecemasan merupakan manifestasi langsung dari stres kehidupan dan sangat erat kaitannya dengan pola hidup (Wibisono, 1990). Hipertensi sering tidak menunjukkan gejala, sehingga baru disadari bila telah menyebabkan gangguan organ seperti gangguan fungsi jantung atau stroke, hal ini dapat menimbulkan rasa cemas penderita hipertensi.

Pada kelompok kontrol responden hanya diberikan leaflet dan diuji quesioner pre dan pos. Sedangkan pada kelompok intervensi selain dilakukan pre dan pos test responden diberikan psikoedukasi tentang hipertensi, faktor penyebab, pencegahan dan pengelolaannya. Responden juga diberikan pengetahuan tentang kecemasan, penyebab dan pengelolaan cemas, serta latihan teknik menurunkan kecemasan dengan relaksasi otot otot progresif dan napas dalam. Pemberian materi dalam penelitian ini menggunakan bahasa yang mudah dimengerti dan menggunakan media power point, buku panduan dan leaflet. Namun hasil analisa tidak ada perbedaan yang signifikan, walaupun tingkat kecemasan ada penurunan. Hal tersebut sesuai dengan pernyataan bahwa adakalanya pendidikan dan pelatihan dianggap kurang optimal. Responden kurang termotivasi untuk melakukan pelatihan dan tidak menerapkan dalam kehidupan.

Tabel 3 menggambarkan distribus kognitif / pengetahuan responden pre dan post pada kelompok kontrol dan intervensi. Rata rata kognitif pre test pada kelompok kontrol adalah 36.05 dengan standar deviasi 1.709 sedang untuk pos test adalah 36.15 dengan standar deviasi 1.994. Hasil uji statistik didapatkan nilai $\mathrm{p}$-value $=0.770$, yang 
berarti pada alpha 5\% terlihat tidak ada perbedaan yang signifikan rata rata kognitif pada pre dan post. Hal ini dimungkinkan responden sudah memahami penyakit yang dideritanya karena sering mendapatkan pengetahuan saat melakukan pemeriksaan kesehatan. Hasil ini sesuai penelitian Khofi Hadidi (2015) dalam penelitian pengaruh psikoedukasi terhadap pengetahuan, koping, kepatuhan dan tekanan darah pada lansia dengan hipertensi, pada kelompok kontrol didapatkan data $\mathrm{p}=$ 0.257 yang artinya tidak ada perubahan pengetahuan responden pre dan post.

Dari tingkat pendidikan pada kelompok kontrol rata rata responden 87.5\% berpendidikan rendah (SD dan SMP) hal ini akan berpengaruh terhadap tingkat pengetahuan responden terhadap penyakit yang dideritanya. Dari hasi analisis pengetahuan responden kognitifnya tinggi. Hal ini bertolak belakang dengan teori bahwa walaupun tingkat pendidikan pasien rendah namun psikoedukasi yang diberikan mampu mengubah pola pikir responden, sehingga dapat meningkatkan pengetahuan responden. Responden mempunyai semangat dan motivasi yang tinggi terhadap kesehatan, hal ini terlihat dari antusiasme pada saat pemeriksaan kesehatan yang dilakukan pihak puskesmas.

Pada kelompok intrvensi rata rata kognitif pada pre test adalah 35.10 dengan standar deviasi 1.194, sedangkan untuk pos test adalah 36.08 dengan standar deviasi 1.966. Hasil uji statistik didapatkan nilai $\mathrm{p}$-value $=$ 0.013 , yang berarti pada alpha $5 \%$ terlihat ada perbedaan yang signifikan rata rata kognitif pada pre dan post kelompok intervensi (Tabel 3).

Tabel 3

Distribus kognitif / pengetahuan Responden Pre dan Pos pada kelompok Kontrol dan Intervensi

\begin{tabular}{llllll}
\hline Variabel & & Mean & SD & SE & P Value \\
\hline Kontrol & Pre & 36.05 & 1.709 & 0.270 & 0.770 \\
& Pos & 36.15 & 1.994 & 0.315 & \\
Intervensi & Pre & 35.10 & 1.194 & 0.189 & 0.013 \\
& Pos & 36.08 & 1.966 & 0.311 & \\
\hline
\end{tabular}


Psikoedukasi, baik individu ataupun kelompok tidak hanya memberikan informasi- informasi penting terkait dengan permasalahan partisipannya tetapi juga mengajarkan keterampilanketerampilan yang dianggap penting bagi partisipannya untuk menghadapi situasi permasalahannya. Hasil diatas menjelaskan bahwa prinsip belajar adalah seumur hidup, bahwa manusia itu memiliki kemampuan untuk belajar sejak lahir hingga akhir hayat. Hal ini senada dengan hasil penelitian Siswoyo (2014) tentang pengaruh psikoedukasi pada pasien katarak dimana mendapatkan hasil bahwa psikoedukasi dapat berpengaruh secara bermakna meningkatkan pengetahuan pasien katarak. Psikoedukasi mampu menegubah jalan pikiran pasien katarak menjadi rasional berdasarkan pengetahuan.

\section{SIMPULAN}

Pada hasil analisis tingkat pengetahuan pada responden kelompok intervensi didapatkan nilai p-value 0.013 yang artinya ada perbedaan antara pre dan pos kognitif pada kelompok intervensi. Hal ini menggambarkan Psikoedukasi yang diberikan mampu meningkatkan pengetahuan responden secara bermakna dari pengetahuan yang pada awalnya tingkat pengetahuan rendah menjadi sedang dan tingkat pengetahuan sedang menjadi tingkat pengetahuan tinggi. Pemberian materi dalam intervensi pada penelitian ini dengan menggunakan power point, buku panduan dan leaflet, dengan metode diskusi dapat diterima dengan baik walaupun responden tergolong lansia dengan rata rata pendidikan yang rendah.

Hasil analisis tingkat kecemasan pada kelompok kontrol dan intervensi baik pre dan post tidak didapatkan adnya perbedaan yang signifikan, namun dari kuantitas kecemasan ada penurunan tingkat kecemasan pada kelompok kontrol dan kelompok intervensi walaupun tidak bermakna. hal ini dikarenakan masyarakat sudah memahami penyakit hipertensi yang telah dideritanya pada waktu yang lama. Responden aktif mengikuti program kesehatan yang diberikan pihak puskesmas

\section{DAFTAR RUJUKAN}

Anderson, D.W., Vault, V.D., \& 
Dickson, C.E. 1999. Problems and Prospects for the Decades Ahead: Competency Based Teacher Education. Berkeley: McCuthchan Publishing Co.

Perry, Patricia A., \& Potter, Anne Griffin. 2005. Fundamental Keperawatan buku I edisi 7. Jakarta : Salemba Medika

Hawari, D. 2013. Manajemen Stres, Cemas dan Depresi. Jakarta : FKUI

Herodes, R. 2010. Anxiety and Depression in Patient.

Hasanat N. \& Ningrum R.R. 2010 Program psikoedukasi bagi pasien diabetes untuk meningkatkan kualitas hidup (Online)(http://ugm.ac.id. Diakses tgl 17 Februari 2018

Nyoman Sudja, Meirina. 2014 Intervensi Psikoedukasi Meningkatkan Kemampuan Pralansia Dalam Penanganan Hipertensi

Bomar, P.J. 2004. Promoting Health in Families: Applying Family Research and Theory to Nursing Practice. Philadelphia: W.B. Sounders Company.

Ellen P. Lukens, \& William. 2004.

Psychoeducation as EvidenceBased Practice: Considerations for Practice, Research, and Policy.

Nurbani. 2009. Pengaruh Psikoedukasi Keluarga terhadap masalah Psikososial ansietas dan beban keluarga (Care giver) dalam merawat pasien Stroke di RSUPN Dr Ciptomangunkusumo Jakarta. , (Online), https://nswayandarsana.blogspot. com/2014/02/pengaruhpsikoedukasi-keluargaterhadap.html Diakses tgl 25 Januari 2018

Notoatmodjo, soekidjo,. 2012. Metodelogi Penelitian Kesehatan . Jakarta. PT Rineka Cipta

Stuart, G. W. \& Laraia, M. T. 2016. Prinsip dan Praktik Keperawatan Kesehatn jiwa STUART Edisi Indoesia. Singapore, Elsevier

Walsh, Joseph 2010 Psychoeducation in mental Health Chicago, Lyceum Book , Inc

Di unduh dari www,academia,edu/31850783.

Makalah Psikologi Klinis

Psikoedukasi . Diakses tgl 8 Februari 2018

Alim. 2009. Langkah-Langkah Relaksasi Otot Progresif http//www.psikologizone.com/Lan gkah-Langkah-Relaksasi-OtotProgresif, diakses tanggal 25 Januari 2018

Videbeck, S.L. 2006. Psychiatric Mental Health Nursing. $\left(3^{\text {rd }}\right.$ edition). Philadhelpia: Lippincott Williams \& Wilkins.

Soekidjo, $\quad$ Notoadmodjo. 2002. Metodologi Penelitian Kesehatan. Jakarta : PT Rineka Cipta.

Faizatur Rohmi, dkk 2015 Pengaruh Psikoedukasi Keluarga Terhadap Tingkat Kecemasan 
Dan Kemampuan Keluarga Dalam Merawat Penderita Tb Di Puskesmas Sumbermanjing Wetan Kecamatan Sumbermanjing Kabupaten Malang, (Online), http://jurnal.unmuhjember.ac.id/ index.php/TIJHS/article/view/44 Diakses tgl 25 Januari 2018

Khofi Hadidi dkk 2015 Pengaruh Psikoedukasi Terhadap Pengetahuan, Koping, Kpetuhan dan Tekanan Darah Pada Lansia Dengan Hipertensi Menggunakan Pendekatan Teori Roy , (Online), http://repository.unair.ac.id/454 54/14/193.\%20TKP.0816\%20Had\%20p.pdf Diakses tgl 8 Februari 2018
Aisyah Dzil Kamalah, Ahsan, Heri Kristianto 2016 Efektivitas Psikoedukasi Keluarga Pada Caregiver Pasien Ulkus Diabetes Melitus Dalam Menurunkan Tingkat Ansietas. , (Online), https://jik.ub.ac.id/index.ph p/jik/article/view/103

Diakses tgl 8 Februari 2018 